\title{
JMS MAсіттовом

\section{Peningkatan Kesadaran Masyarakat untuk Gemar Makan Ikan: Pelatihan Pembuatan Es Dawet Belut Manis}

\author{
Novia Anggraeni \\ Luqmanul Hakim \\ Fath Fadhilah. W \\ Universitas Nasional Karangturi; nanggreani9@gmail.com. \\ Universitas Diponegoro \\ Universitas Diponegoro
}

A R T I C L E I N F O

Article history:

Received 12-07-2020

Revised 30-07-2020

Accepted 25-08-2020

Key words:

Pelatihan, Es Dawnis, Belut

\begin{abstract}
A B S T R A C T
The training on making Es Dawet Belut Manis (dawnis) was motivated by the abundance of produce from eel cultivation in Kandri Village, like the lack of consumption of fish in Indonesia. The aim of this program is to increase the use of eels as an effort to promote the movement to eat fish. This program focuses on Kandri Tourism Village people, there are three stages, namely exposure to the potential and nutritional content of eels, training in Es Dawnis making and marketing of Es Dawnis. From the three stages, it can be concluded that the Ice Dawnis making training program has been successfully implemented by observing the enthusiasm of the participants, product acceptance, and product marketing that could potentially introduce Es Dawnis as a typical drink for Kandri Tourism Village.
\end{abstract}

\section{A B S T R A K}

Pelatihan pembuatan Es Dawnis dilatar belakangi oleh melimpahnya hasil dari budidaya belut di Desa Kandri, serta kurangnya konsumsi ikan di Indonesia. Program ini bertujuan untuk meningkatkan pemanfaatan belut sebagai upaya menggalakkan gerakan gemar makan ikan. Program ini berfokus masyarakat Desa Wisata Kandri terdapat tiga tahapanya itu pemaparan mengenai potensi dan kandungan gizi belut, pelatihan pembuatan Es Dawnis, dan pemasaran Es Dawnis. Dari ketiga tahapan tersebut dapat disimpulkan bahwa program pelatihan pembuatan Es Dawnis telah berhasil dilaksanakan dengan melihat antusias peserta, penerimaan produk, serta pemasaran produk yang dapat berpotensi mengenalkan Es Dawnis sebagai minuman Khas DesaWisata Kandri. 


\section{PENDAHULUAN}

Kota Semarang merupakan ibukota dari Provinsi Jawa Tengah dengan perkembangan sangat pesat serta fasilitas yang sangat memadai seperti pelabuhan, pendidikan, kesehatan, perbelanjaan, kawasan bisnis. Pemerintah Kota Semarang selalu mengembangkan potensinya untuk menurunkan angka kemiskinan masyarakat dengan cara menjadi kota jasa pariwisata. Perkembangan Kota Semarang menjadi kota jasa itu ditunjukkan dengan adanya fasilitas bandara Ahmad Yani sebagai Bandara Internasional, maupun transportasi Kereta Api (KA) dan bus dengan tujuan berbagai kota. Salah satu daya tarik dari Kota Semarang adalah banyaknya destinasi wisata serta desa wisata yang sudah mulai berkembang baik di tingkat nasional maupun internasional.

Peranan pariwisata dalam perekonomian nasional berbagai negara sangat penting (Bălan dan Burghelea, 2015). Hal ini dikarenakan perkembangan pariwisata akan semakin meningkat seiring berjalannya waktu. Perkembangan ekonomi dan social akan terjadi apabila pemerintah menciptakan dan mengembangkan pariwisata di negaranya. Beberapa hal yang dapat dilakukan pemerintah yaitu dengan mendorong perkembangan cabang-cabang ekonomi nasional lainnya melalui subjek aktivitasnya seperti industri dan pertanian, konstruksi, transportasi, perdagangan, dan sektor lainnya.

Desa Wisata Kandri berada pada Kecamatan Gunung Pati Kota Semarang. Desa wisata Kandri adalah salat satu tujuan destinasi wisata pada Kota Semarang lantaran desa ini masih alami serta menyajikan pemandangan alam dan keindahannya. Desa ini adalah desa wisata lantaran memiliki banyak potensi mulai berdasarkan alam hingga menggunakan budaya aslinya yang masih dilestarikan. Terdapat juga kerajinan batik, sulam, dan budidaya belut. Selain itu, ada juga beberapa loka wisata populer pada Desa Kandri diantaranya adalah Goa Kreo \& Waduk Jatibarang.

Kegiatan pemberdayaan masyarakat yang sudah dilakukan di Desa Wisata Kandri adalah dengan membentuk kader pemberdayaan yang berjumlah dua belas orang. Tugas dari kader pemberdayaan ini adalah sebagai pelopor penggerak masyarakat Desa Wisata Kandri agar berpartisipasi dalam pemberdayaan yang diselenggarakan oleh pihak internal maupun eksternal. Sehingga dapat mempertahankan predikat Desa Kandri sebagai Desa Wisata yang ada di Ibu Kota Jawa Tengah. Selain terdapat kader pemberdayaan, juga terdapat kelompok sadar wisata. POKDARWIS (Kelompok Sadar Wisata) yang terdiri dari POKDARWIS Pandanaran dan POKDARWIS Sukomakmur.

POKDARWIS di Desa Wisata Kandri bertujuan untuk memicu partisipasi masyarakat sekitar dalam bidang kepariwisataan serta menumbuhkan dukungan positif masyarakat sebagai tuan rumah kepariwisataan yang nantinya juga akan meningkatan kesejahteraan masyarakat di Wilayah Desa Kandri melalui sektor pariwisata. Selain itu, POKDARWIS juga berperan sebagai inisiator beberapa gagasan yang akan dipasarkan pada desa wisata Kandri baik dalam sisi sosial, lingkungan, maupun ekonomi. Sektor pariwisata akan berkelanjutan jika pembangunan memperhatikan beberapa aspek penting yaitu lingkungan, sosial, dan ekonomi (Risteskia, Kocevskia and Arnaudov, 2012).

Salah satu potensi Desa Kandri yang akan ditonjolkan oleh POKDARWIS 
adalah budidaya belut. Saat ini, potensi budidaya belut belum dimanfaatkan secara maksimal. Hanya dijual secara mentah dan belum terdapat produk olahan dari belut itu sendiri. Manfaat yang terkandung pada daging belut bagi kesehatan yaitu sebagai salah satu contoh sumber protein berasal dari kelompok hewani yang dibutuhkan oleh tubuh. Sehingga belut dapat dijadikan makanan alternatif yang dapat memenuhi kebutuhan protein harian tubuh.

Pelatihan ini akan mengajarkan prinsip diversifikasi produk yaitu dengan mengubah belut yang biasanya hanya digoreng/ dibakar menjadi produk minuman tradisional yang unik dan bergizi tinggi. Pelatihan pembuatan Es Dawnis mendukung program pemerintah yaitu gemar makan ikan. Seperti yang diketahui bahwa konsumsi makan ikan di Indonesia masih rendah. Pelatihan ini diharapkan dapat meningkatkan tingkat konsumsi makan ikan dan menambah keanekaragaman produk kuliner yang ada di Indonesia khususnya Desa Wisata Kandri.

\section{METODE PELAKSANAAN}

Metode pengabdian masyarakat dilaksanakan dengan memberikan sosialisasi dan pelatihan yang meliputi sosialisasi tentang potensi belut, dan memberikan pelatihan pembuatan Es Dawnis. Peserta dalam pelatihan ini yaitu anggota POKDARWIS, pembudidaya belut dan masyarakat Desa Kandri Semarang. Pengambilan data dilakukan dengan mengambil dokumentasi, kuesioner, dan wawancara. Tahapan dalam kegiatan pengabdian masyarakat terdiri dari tiga tahap, diantaranya adalah tahap I (sosialisasi dan pemberian materi tentang potensi dan kandungan gizi belut), tahap II (pelatihan pembuatan Es Dawnis terdiri dari beberapa proses yaitu: pemilihan bahan baku, pembersihan bahan baku, pemotongan, perebusan, pencampuran adonan, pemasakan, pencetakan, dan penyajian), dan tahap III (pemasaran Es Dawnis).

\section{HASIL DAN PEMBAHASAN}

Rangkaian program pelatihan pembuatan Es Dawnis diselenggarakan dalam rangka menciptakan produki unggulan Desa Wisata Kandri. Peserta yang mengikuti pelatihan terdiri dari anggota POKDARWIS, pemilik kolam budidaya belut dan masyarakat sekitar dengan total peserta 50 orang. Berdasarkan Gambar 1. Terlihat bahwa mayoritas peserta yang mengikuti adalah masyarakat umum. Hal ini dikarenakan rasa ingin tahu dari masyarakat akan produk Es Dawnis (Es Belut Manis). Selain itu juga tingkat konsumsi makan ikan di Desa Kandri sendiri cukup tinggi, sehingga semakin menambah antusias memasyarakat Desa Kandri. Hal ini sesuai dengan pendapat dari (Nantanga dan Amakali, 2020), menyatakan bahwa produk diversifikasi mempunyai daya tarik tertentu dan cocok dikembangkan oleh Usaha Miko Kecil Menengah karena prosesnya yang mudah dan bahan baku yang melimpah. 


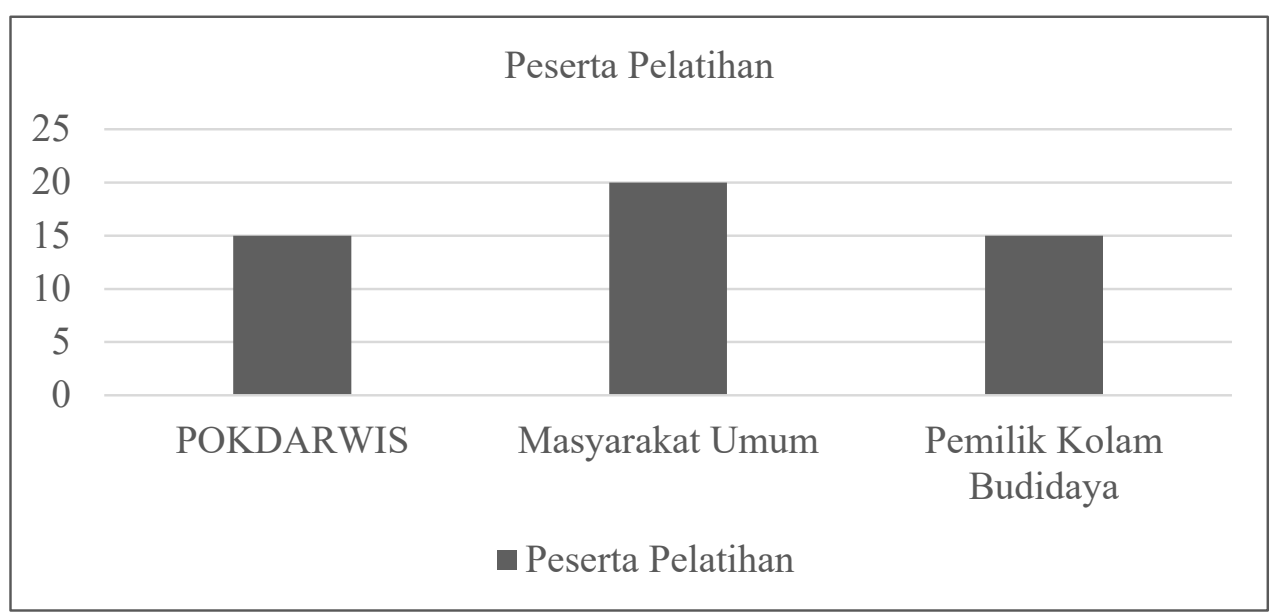

Gambar 1. Pemetaan Jumlah Peserta

Tahap pertama yang dilakukan pada pelatihan ini adalah sosialisasi dan pemberian materi tentang potensi dan kandungan gizi belut. Belut merupakan hewan menyerupai ular yang tergabung dalam kelompok Synbranchidae. Belut sering disamakan dengan sidat karena bentuknya yang hampir sama. Namun sejatinya belut berbeda dengan sidat. Belut tidak memiliki sirip, sementara sidat masih memiliki sirip. Selain itu, ketersediaan belut di Desa Kandri sendiri cukup melimpah, sehingga berpotensi untuk dijadikan produk yang dapat menambah nilai jual dari belut itu sendiri. Potensi dari hasil perikanan budidaya seperti ikan belut sangat tinggi (Zhang et al., 2019). Hal ini disebabkan karena produksi hasil perikanan budidaya terus meningkat setiap tahunnya.

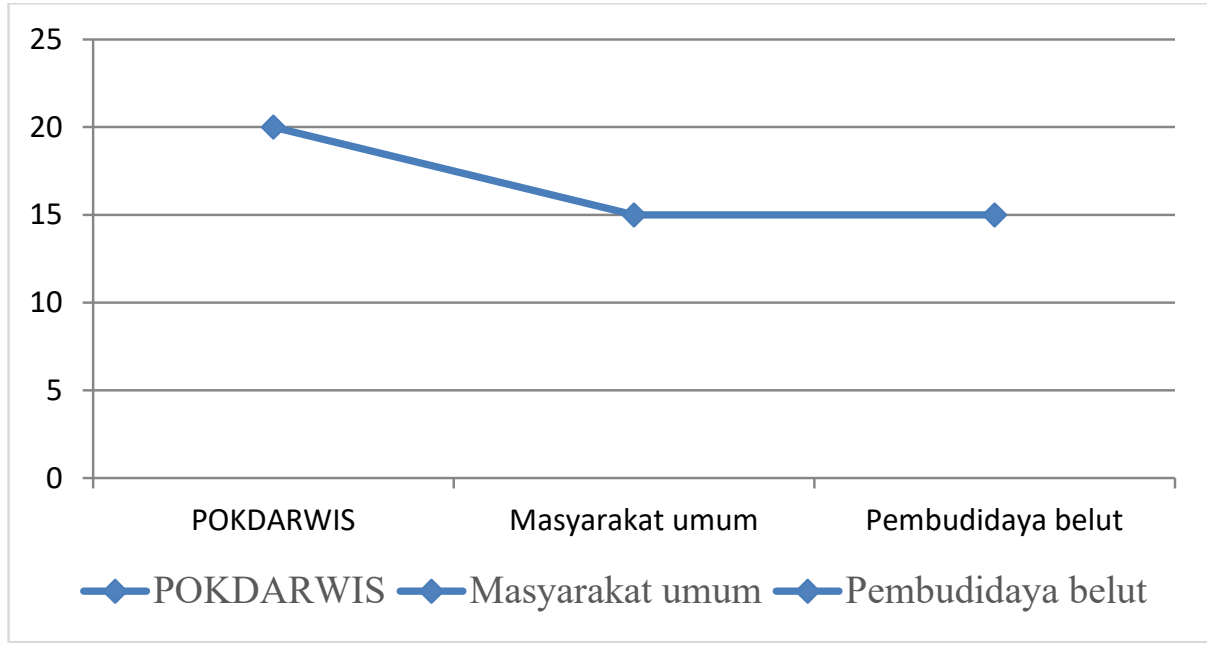

Gambar 2. Prosentase Pengetahuan Peserta tentang Diversifikasi Produk 
Salah satu materi yang disosialisasikan pada tahap pertama adalah pengenalan mengenai diversifikasi pangan. Berdasarkan Gambar 2. Terlihat bahwa prosentase pengetahuan peserta tentang diversifikasi produk sudah diatas $10 \%$. Peserta pengabdian masyarakat sudah banyak yang mengetahui prinsip dasar diversifikasi makanan walaupun dengan istilah yang berbeda. Hal ini dibuktikan dengan adanya beberapa olahan singkong seperti kripik, getuk yang sudah diproduksi oleh masyarakat Desa Kandri sebagai makanan oleh-oleh. Diversifikasi adalah salah satu upaya menciptakan inovasi produk dari satu jenis bahan baku.

Tujuan diversifikasi adalah untuk memberikan alternatif makanan agar masyarakat tidak terpaku pada satu jenis produk saja, serta dapat menciptakan produk dengan gizi yang lengkap. Pendapat (Anggraeni, Sastro Darmanto dan Riyadi, 2016) menyatakan bahwa untuk memenuhi kebutuhan gizi zat mikro ataupun makro dibutuhkan alternative produk baru hasil subsitusi dengan bahan lainnya. Begitu pula dengan penelitian (Frison dan Clément, 2020), yang menyatakan bahwa menciptakan produk yang sehat dan beraneka adalah salah satu cara terbaik untuk mengatasi kasus kekurangan gizi mikro maupun makro.

Tahap kedua pada kegiatan pengabdian masyarakat adalah pelatihan pembuatan es dawnis yang dilakukan dengan cara demonstrasi seperti pada Gambar 3 . Pelatihan ini juga memberikan materi tentang program gemar ikan yang sedang digalakkan oleh pemerintah. Program gemar ikan atau gerakan makan ikan ini bertujuan untuk meningkatkan konsumsi ikan di masyarakat, karena hasil perikanan di Indonesia cukup melimpah, namun tingkat konsumsi ikan masyarakat Indonesia mencapai 54,49 kg, lebih rendah dari Malaysia yang mencapai $70 \mathrm{~kg}$ (Kementrian Kelautan dan Perikanan, 2017). Sehingga program gemar ikan sangat perlu untuk disosialisasikan agar dapat meningkatkan konsumsi makan ikan masyarakat Indonesia.

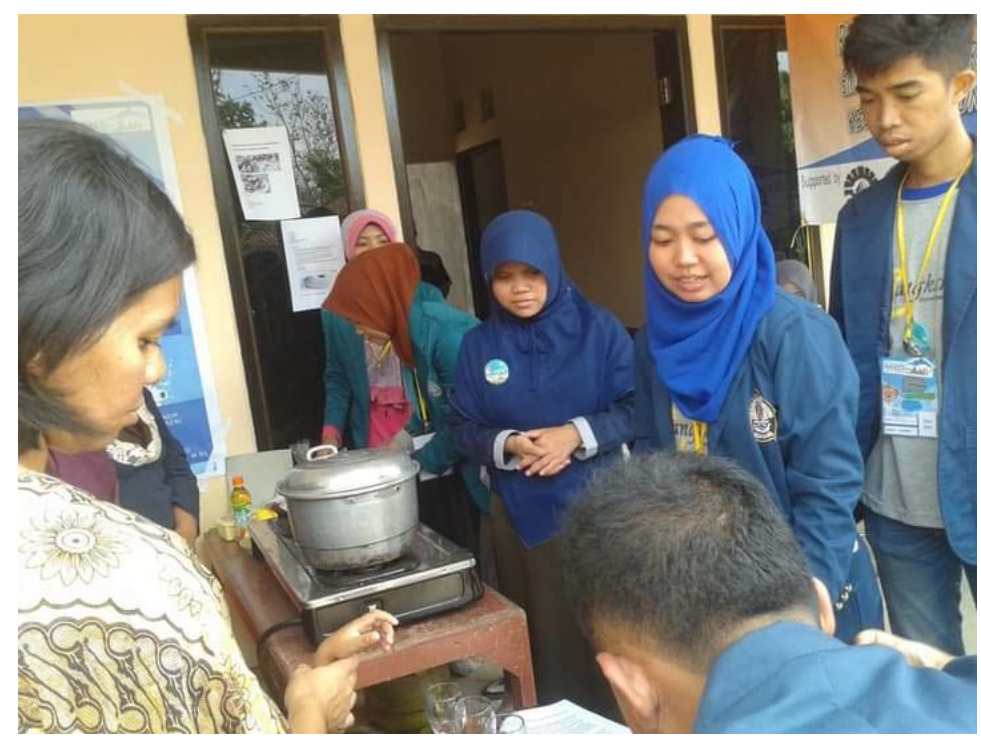

Gambar 3. Proses Pelatihan Pembuatan Es Dawnis

Pembuatan Es Dawnis dengan bahan baku daging belut ini merupakan salah 
satu upaya untuk menciptakan produk khas yang unik. Daging belut ini digunakan sebagai bahan baku pembuaatan cendol dari Es Dawet. Belut pada Gambar 4. diperoleh dari pembudidaya belut di Desa Kandri Semarang sehingga terjamin kualitas dan kesegarannya. Kesegaran dari belut merupakan faktor utama penentu kualitas dari cendol. Parameter dari kesegaran ikan ini dinilai dengan menggunakan uji sensori dengan melihat kenampakan belut secara fisik. Hal ini diperkuat oleh (Prabhakar et al., 2020) yang menyatakan bahwa kesegaran daging ikan merupakan faktor penting dalam pada kualitas produk. Parameter kesegaran ikan yang dapat dipilih diantarannya sensorik, fisik, kimia dan mikrobiologi.

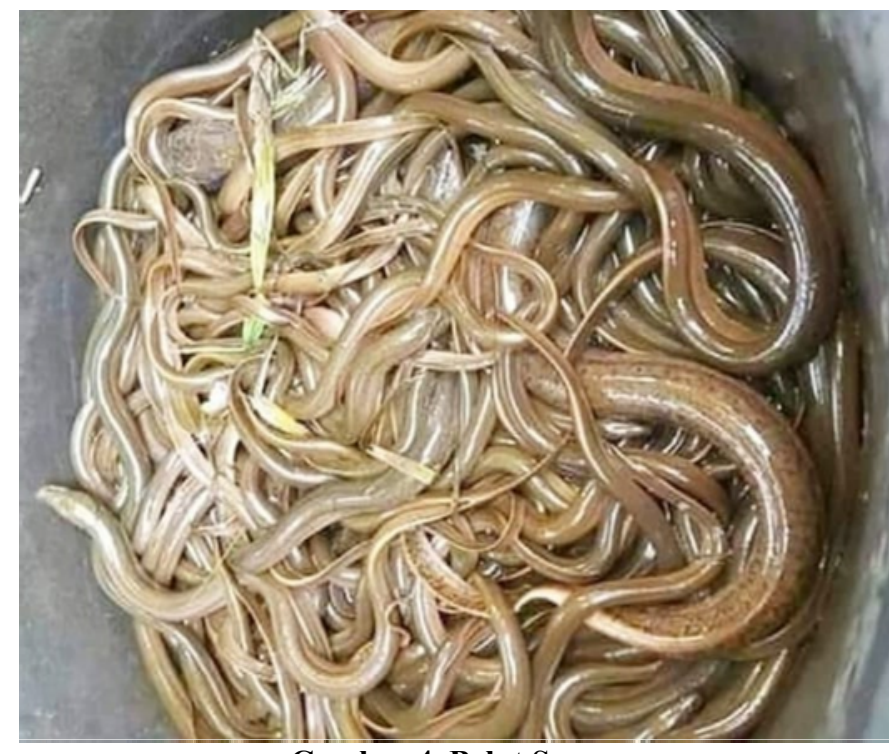

Gambar 4. Belut Segar

Proses pembuatan cendol berbahan baku belut terdiri dari beberapa proses. Tahap pertama yaitu membersihkan belut dari sisa kotoran serta mengeluarkan isi perut belut. Selanjutnya belut dipotong menjadi beberapa bagian untuk dikukus selama 10 menit seperti yang terlihat pada Gambar 5. Tahapan ketiga yaitu menghaluskan daging belut yang sudah dikukus, untuk kemudian dicampurkan dengan bahan pembuat cendol lainnya seperti tepung beras dan tepung tapioka. Pewarnaan cendol dilakukan dengan menambahkan air rebusan daun suji. Tahap terakhir adalah pencetakan cendol dengan menggunakan cetakan cendol. Lalu cendol disajikan dengan tambahan santan dan gula aren yang kemudian disebut dengan Es Dawnis (Dawet Belut Manis). 


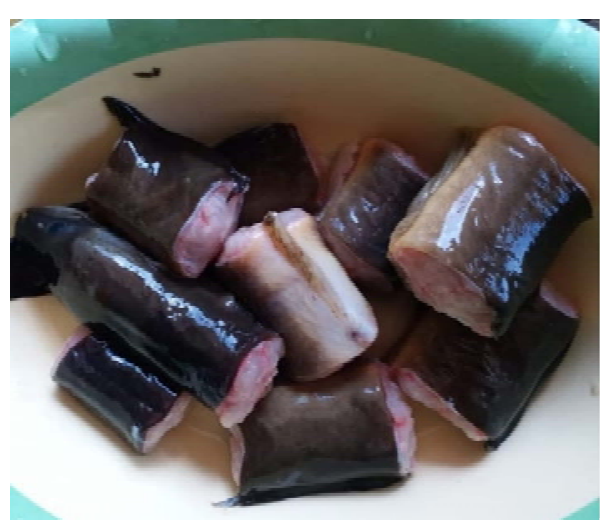

Gambar 5. Irisan Daging Belut

Produk Es Dawnis yang berasal dari belut akan dijadikan minuman khas Desa Wisata Kandri dengan harapan akan menambah jumlah wisatawan yang datang. Selain itu, kandungan gizi dari belut sendiri dapat mencukupi kebutuhan konsumsi harian protein. Menurut penelitian (Hu et al., 2020) dalam 100 gram daging belut terdapat 17,15 gram. Jumlah protein ini masih lebih tinggi jika dibandingkan dengan produk es dawet di pasaran yang hanya memiliki protein 11,35 gram. Sehingga dapat dikatakan belut memiliki protein yang cukup tinggi. Di sisi lain, belut memiliki tekstur daging kenyal serta rasa yang menarik sehingga sangat mudah diolah menjadi produk Es Dawnis (Gambar 6.) tanpa mengubah cita rasa dari belut itu sendiri. Penelitian (Hu et al., 2019) menyatakan bahwa belut sawah (Monopterus albus) adalah spesies ekonomis yang cukup popular karena rasanya yang enak dan mudah dikomersialkan.

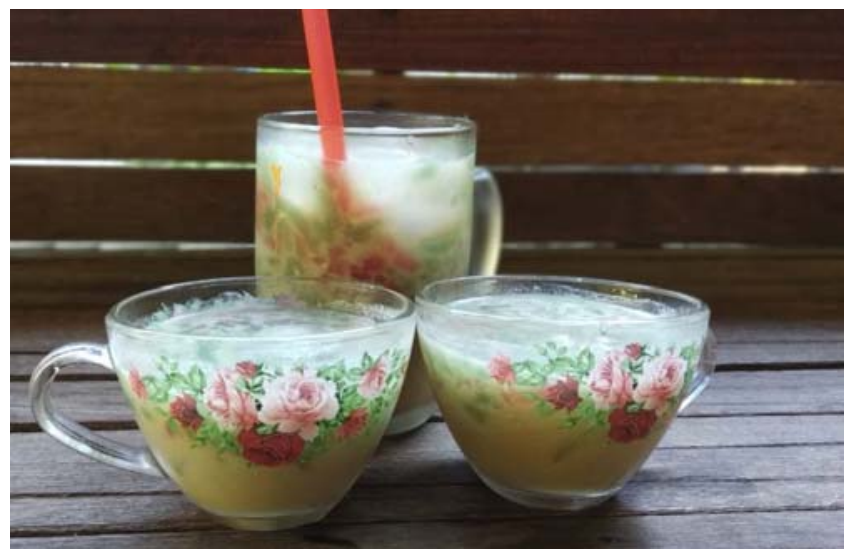

Gambar 6. Produk Es Dawnis

Salah satu parameter keberhasilan pembuatan Es Dawnis adalah penerimaan produk dari peserta pelatihan. Penerimaan produk ini sering disebut dengan uji organoleptik yang dilakukan dengan parameter meliputi tekstur, penampakan, warna, aroma, rasa, dan bau. Uji organoleptik ini berupa uji kesukaan terhadap produk Es Dawnis. Skala yang digunakan untuk uji organoleptik produk Es Dawnis dapat dilihat pada Tabel 1. Penilaian penerimaan konsumen juga dilakukan pada penelitian (Madzharov, 2019) yang menyatakan bahwa uji penerimaan produk dapat dilakukan dengan uji organoleptik dengan skala hedonik . 
Tabel 1. Penilaian Uji Organoleptik

\begin{tabular}{cc}
\hline Skala Numerik & Skala Hedonik \\
\hline 9 & Amat Sangat suka \\
8 & Sangat Suka \\
7 & Suka \\
6 & Agak suka \\
5 & Netral \\
4 & Agak tidak suka \\
3 & Tidak Suka \\
2 & Sangat tidak suka \\
1 & Amat sangat tidak suka \\
\hline
\end{tabular}

Hasil uji organoleptik tersaji pada Gambar 7 yang menunjukkan bahwa produk Es Dawnis dapat diterima oleh sebagian besar peserta pelatihan. Skala penilaian tertinggi pada uji organoleptik adalah 7 yang artinya adalah suka. Dengan adanya penerimaan produk Es Dawis, maka dapat disimpulkan bahwa peserta memiliki ketertarikan terhadap produk tersebut. Sehingga produk Es Dawnis layak untuk terus dikembangkan dengan mngevaluasi tekstur, penampakan, warna, aroma, rasa, dan bau pada uji organoleptik. Menurut pendapat (Lima Filho et al., 2020) uji kesukaan yang sering digunakan dalam produk pangan biasanya menggunakan parameter warna, rasa, tekstur, dan aroma. Berikut pemaparan dalam bentuk grafik mengenai hasil uji arganolepatik.

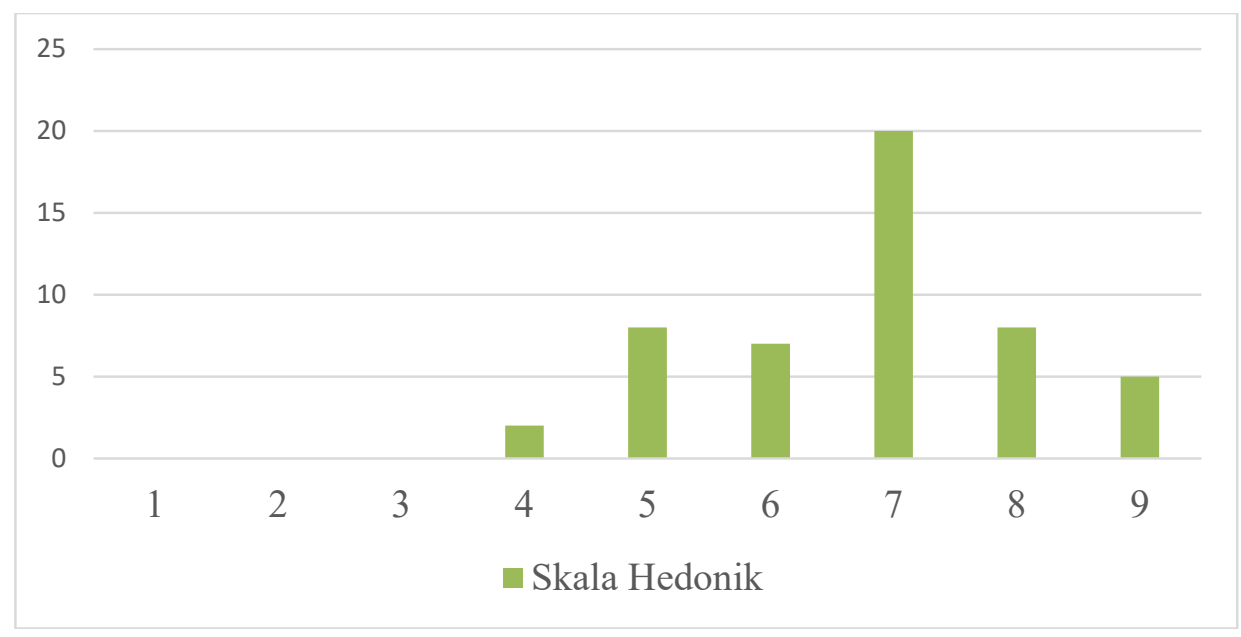

Gambar 7. Hasil Uji Organoleptik

Tahap terakhir yang dilakukan pada pengabdian masyarakat ini adalah pemasaran produk. Pemasaran adalah salah satu faktor yang dapat dijadikan tolak ukur dari berkembangnya suatu produk yang akan dipasarkan. Produk Es Dawnis ini akan dipasarkan melalui media digital seperti facebook, Instagram, dan youtube dari Desa Wisata Kandri. Selain itu, pemasaran produk yang dapat dilakukan antara lain mencantumkan produk Es Dawnis di setiap paket wisata yang ditawarkan oleh POKDARWIS. Peran masyarakat sekitar juga sangat dibutuhkan untuk memasarkan 
produk Es Dawnis, sehingga nantinya produk Es Dawnis dapat dijadikan minuman khas Desa Wisata Kandri.

\section{SIMPULAN}

Berdasarkan beberapa tahapan pengabdian masyarakat yang telah dilaksanakan ini dapat disimpulkan bahwa pelatihan pembuatan Es Dawnis merupakan serangkaian program untuk menciptakan produk unggulan dalam hal ini minuman khas Desa Wisata Kandri agar dapat meningkatkan jumlah wisatawan yang datang. Pelaksanaan pelatihan ini dilaksanakan dengan tiga tahapan. Dari ketiga tahap dapat disimpulkan bahwa target luaran sudah tercapai dengan kata lain dapat disimpulkan bahwa program ini berhasil dilaksanakan dan berpotensi untuk terus dikembangkan di Desa Wisata Kandri.

\section{DAFTAR PUSTAKA}

Anggraeni, N., Sastro Darmanto, Y. and Riyadi, P. H. (2016) 'Pemanfaatan Nanokalsium Tulang Ikan Nila (Oreochromis niloticus) pada Beras Analog dari Berbagai Macam Ubi Jalar (Ipomoea batatas L.)', Jurnal Aplikasi Teknologi Pangan, 5(4), pp. 114-122. doi: 10.17728/jatp.187.

Bălan, M. and Burghelea, C. (2015) 'Rural Tourism and its Implication in the Development of the Fundata Village', Procedia - Social and Behavioral Sciences, 188(1360 m), pp. 276-281. doi: 10.1016/j.sbspro.2015.03.393.

Frison, E. and Clément, C. (2020) 'The potential of diversified agroecological systems to deliver healthy outcomes: Making the link between agriculture, food systems \& health', Food Policy, (February). doi: 10.1016/j.foodpol.2020.101851.

$\mathrm{Hu}, \mathrm{Y}$. et al. (2019) 'Examining and optimizing the BCycle bike-sharing system - A pilot study in Colorado, US', Applied Energy, 247(February), pp. 1-12. doi: 10.1016/j.apenergy.2019.04.007.

$\mathrm{Hu}$, Yajun et al. (2020) 'Effect of partial black soldier fly (Hermetia illucens L.) larvae meal replacement of fish meal in practical diets on the growth, digestive enzyme and related gene expression for rice field eel (Monopterus albus)', Aquaculture Reports, 17(February). doi: 10.1016/j.aqrep.2020.100345.

Lima Filho, T. et al. (2020) 'The hedonic thresholds methodology varying two stimuli: Extending the range of sensory threshold applications', Food Quality and Preference, 86(June), p. 104003. doi: 10.1016/j.foodqual.2020.104003.

Madzharov, A. V. (2019) 'Self-Control and Touch: When Does Direct Versus Indirect Touch Increase Hedonic Evaluations and Consumption of Food', Journal of Retailing, 95(4), pp. 170-185. doi: 10.1016/j.jretai.2019.10.009.

Nantanga, K. K. M. and Amakali, T. (2020) 'Diversification of mopane caterpillars (Gonimbrasia belina) edible forms for improved livelihoods and food security', Journal of Arid Environments, 177(March), p. 104148. doi: 10.1016/j.jaridenv.2020.104148.

Prabhakar, P. K. et al. (2020) 'A comprehensive review on freshness of fish and 
assessment: Analytical methods and recent innovations', Food Research International, 133(February), p. 109157. doi: 10.1016/j.foodres.2020.109157.

Risteskia, M., Kocevskia, J. and Arnaudov, K. (2012) 'Spatial Planning and Sustainable Tourism as Basis for Developing Competitive Tourist Destinations', Procedia - Social and Behavioral Sciences, 44, pp. 375-386. doi: 10.1016/j.sbspro.2012.05.042.

Zhang, J. et al. (2019) 'Replacement of fish meal with soy protein concentrate in diet of juvenile rice field eel Monopterus albus', Aquaculture Reports, 15(September). doi: 10.1016/j.aqrep.2019.100235. 